\title{
Investigation into the acquisition of statutory status for the South African LIS sector
}

\author{
Reggie Raju' \\ G.M.J. Sweeney Law Library, University of KwaZulu-Natal \\ rajur@ukzn.ac.za
}

\begin{abstract}
Received:20 2 th October 2005
Accepted: 7th April 2006

The issue of statutory status was raised by the Special Libraries Interest Group at the 2004 LIASA conference AGM. The Executive Committee of LIASA mandated the author to research the issue of statutory representation of the South African LIS sector. This paper reports on this investigation. The author reviewed the relevant literature to determine the factors that have contributed to the continued existence of LIS professional associations and to examine the transformation of LIS representation from an occupational association to a professional association and back to an occupational association. The author uses case studies to explore the three possible routes for the profession to debate. The paper recommends a referendum be held within the profession to determine a way forward.
\end{abstract}

Keywords: LIASA, professional associations, statutory status for LIS sector, trade unions

\section{Introduction}

At the Annual General Meeting of the 2004 Library and Information Association of South Africa (LIASA) conference, the Special Libraries Interest Group (LISLIG) of LIASA tabled the motion that "LIASA seek full statutory recognition as the sole professional body for the knowledge, records management and library and information workers in South Africa" (LIASA 2004). The Executive Committee of LIASA mandated the author to assess statutory professional representation within the LIS sector and to expose possible ways forward. The probe for suitable ways forward, in the opinion of the author, had to take into consideration the factors that have influenced the continued existence of professional associations. Professional associations continue to exist despite major challenges, especially in the South African environment, from trade unions for the same membership. Therefore, it was crucial that the factors that have contributed to the continued existence of LIS professional associations at a national and international level be identified to ensure that these factors contribute to the core principles that would lay the foundation of any new representative organisation as they have stood the test of time. It is argued that the investigation into these factors would add value to the debate on the most appropriate route that could be adopted for the LIS sector in South Africa.

Given that there was a proposal for LIASA to change, it was important to examine how representation of the LIS sector has evolved over the years. The fundamental purpose of this historical overview was to contribute to an understanding as to whether the proposed debate on the way forward contributes to the evolutionary process continuum or does it contradict that continuum.

Central to this investigation was the acquisition of statutory status. A simple understanding of statutory status is the acquisition of a status that is attained through a legislative process. There are two options through which statutory status can be achieved, namely, (I) registration through an existing statute or (2) the initiation of a new legislation that is specific to the discipline. In terms of the former (existing legislation), the Labour Relations Act (LRA) 66 of 1995 makes provision for the registration of a group of employees to regulate relations between employees and employers. In terms of the latter, the sector would seek the enactment of a new legislation whose primary objective would be to protect the interest of the public and regulate those that enter (for employment purposes) the profession.

The fundamental purpose of this article is to fuel the debate on the issue of statutory status and the significance of such a status to the LIS sector in a labour dispensation that openly promotes trade unionism.

\section{Method and procedure}

In addition to a review of the relevant literature, the author used case studies to solicit information on statutory status of professional organisations. According to Babbie and Mouton (2005: 28I) a case study is an investigation into a single unit. The author was of the opinion that it would be best to investigate the issue of a way forward by examining single units that have acquired statutory status.

Case studies, in the view of Rossman and Rallis (1998: 70-7I), seek to understand a larger phenomenon through examination of a specific case as it illustrates the complexities of a situation and depicts how the passage of time has

I. Reggie Raju, PhD, is the Librarian, G.M.J. Sweeney Law Library, University of KwaZulu-Natal, South Africa 
shaped events. The author used this method to gather information on professional organisations that have acquired statutory status using existing legislation (Labour Relations Act 66 of 1995) and legislation specific to the discipline.

As stated earlier, there are factors that have influenced the continued existence of LIS professional associations. It is argued that these factors should contribute to the core principles governing any new representative organisation.

\section{Factors that have influenced the continued existence of professional associations}

Library associations have relied on a number of factors, in different combinations, to retain or grow their rnembership. The membership has been influenced by the principle of unity, the need for belonging, a sense of professional security, personal professional development, good communication on the part of the association, high library ethics and the support for intellectual freedom and associations as relevant sources of information.

\subsection{Need for belonging}

\%

Library associations have played an important role in bringing librarians together. By coming together, library association members were given the opportunity to develop a sense of professionalism. Furthermore, by banding together, librarians were able to share professional concerns with other librarians. Sullivan (1976: 137) argues that the individual member seeks association membership in order to establish his/her own identity as a member of the library profession or, given the latitude most library associations offer, to indicate his/her interest in librarianship and its improvement. It is argued by Garry (1977: 318) that library associations provide the opportunity for librarians to come together and provide support and reinforce a sense of professionalism and belonging. The sense of professionalism and need for belonging are nurtured via participation in professional associations. Conferring with professionals from other institutions not only provides additional perspectives on issues but also enhances one's status as a professional. The values and ethics of professionalism rise to the surface and are very evident in the activities of professional associations (Frank 1997: 314).

\subsection{Security}

Library associations, writes Garry (1977: 318), serve the important function of providing their members with a sense of security. By coming together in groups, librarians have developed and strengthened professional ideologies which are shared with fellow members of the library profession.

Library associations also serve to protect individual members from unjust treatment by their seniors thereby providing a sense of security. While the association does not have the statutory support during intervention, it has the ability to employ moral persuasion (Garry 1977: 318-319).

\subsection{Personal development}

Education, continuing professional development, lobbying and accreditation of qualifications has always been an attraction of library associations for library staff. To meet the education and continuing professional development of its rnembership, associations have sponsored workshops, panel discussions and guest speakers, for example, either as special events or incorporated into regular meetings (Garry 1977: 320; Fisher 1994: 167).

Library associations have played an important role in personal and professional development of their membership. This is especially true in an academic organisation where library staff have to adjust to changing circumstances which often lead to a re-distribution of 'professional' tasks. As a direct product of this re-distribution, some of the work that used to be performed by professional staff is now performed by support staff as they have sufficient experience and institutional training. Rather than stop this 'de-skilling' and 'de-professionalizing', library associations are obliged to support it. In supporting this 'de-skilling' and 'de-professionalizing', library associations are extending their developmental role towards those without conventional qualifications. It is essential to ensure that competence in library procedures remain the single most important feature governing the future education and training of all those engaged in library and information work (Fisher 1994: 167-168).

\subsection{Self help}

The library association has provided the forum for librarians to come together to form a number of formal or informal networks to share resources, ranging from exclusive networks of university libraries to informal networks of specialized librarians. The mutual assistance offered by members of these networks has become formalized in different ways (Garry 1977: 321).

Professional associations also provide the basis for the development of effective leadership. Frank (1997: 310-31I) argues that leadership, administration, management and supervision are interdependent concepts and practices. All are concerned with behaviours and interaction patterns, role relationships, influence, motivation and goalsi or desired outcomes. Further, all are concerned with the ability or capacity to provide focus and direction for individuals and groups. Opportunities to develop these skills are numerous via active participation in professional associations. Service on committees, for example, exposes the librarian to various planning and implementation processes. According to Sullivan 
(1976:144-145) the activity and accomplishments in an association have led many librarians to positions to which they might never have aspired to or even been aware of, if it were not for their affiliation with the association.

\subsection{Communication}

National library associations have the capacity to maintain a national and cultural identity by keeping the profession informed and maintaining cohesiveness. Effective communication channels, which most national library associations have, keep members of the profession informed of new practices and procedures and emerging technological developments (Garry 1977: 326-327).

Professional associations also use their publications as tools for communicating with their membership. Besides using the publication as a communication tool, it is also used as a development tool. Participation in professional associations provides opportunities to become familiar with the processes of research and publication. These important processes contribute to the librarian's professional development. Creativity and innovation are expressed as ideas, concepts are considered and integrated, and new information is generated (Frank 1997: 31 I).

Further, publication creates the opportunity to engage in scholarly processes. Professional associations sponsor conferences at local and national levels. Associations call for papers to be presented at these conferences, thereby providing the membership with opportunities to do research and to discuss the results of such research at a forum of colleagues. Presenting a paper to a group of peers, listening to their comments and suggestions, and responding to their questions constitute several of the key elements of critical dialogue. Such participation tends to bring the profession closer as it presents the opportunity of developing the profession through research and engaging colleagues in discussion (Frank 1997: 313).

\subsection{Library ethics}

Oppenheim and Pollecutt (2000: 189-190) state that a professional association often has a code of ethics or conduct which is the embodiment of the ideals and responsibilities of a professional group. The general guidance of the code may be used when a practitioner has to make a difficult judgement. It gives reassurance that the decision taken is in accordance with the generally agreed principles and values of the profession. It can also be used by the individual to defend his or her actions. However, such a code needs to be backed by a professional association to be effective in protecting the profession and its clients. Clients expect a high level of ethical commitment from practioners and should be assured that they will receive this. Sanction by the association protects the reputation of the profession.

The roles of professional associations with regard to ethical issues have not been debated in depth in the library and information science literature. However, according to Oppenheim and Pollecutt (2000: 197) and Stabbins (1990: 19-22) there is sufficient evidence to indicate that professional associations do provide a valuable role in focusing the attention of its members on ethical issues. Such focus and protection by the association has served the association well in attracting and retaining its membership, especially the professional members.

\subsection{Intellectual freedom}

Intellectual freedom of opinion and expression, and its support thereof, are core principles governing librarianship. Frank (1997: 315) points out that "intellectual freedom must be protected" by the professional association. The user, in principle, should have unfettered access to most information. Any exceptions to such access should be tightly monitored. Government should make available to its citizens the information used by them for decision making. They should disclose such information to those requesting it, except for a small number of exceptional circumstances, for example, to protect national security.

Oppenheim and Pollecutt (2000: 188-189) argue that for a democratic society to function correctly, its citizenry must be able to make informed decisions about the actions of the legislature and all other powerful groups. Further, the citizens should be free to express themselves provided such expressions do not harm others. Given the fact that such intellectual property resides in a library environment, library staff should encourage transparency and at the same time protect copyright. The underlying principle is that freedom of information and data protection are vital to enable society to keep a check on those advantaged in the unequal relationship.

\subsection{Library associations as relevant sources of information}

According to Virgo (1991: 189) associations are a body of people who collectively have a wealth of experiences to draw upon from a common discipline. This collection of experiences is what gives value to a professional association for the librarian.

Active participation on committees in professional associations is a particularly effective method of obtaining relevant information. Most librarians agree that committees are important and that effectively run committees are fundamental to the success of the associations. Committees and task forces have specific responsibilities. Participants of committees become familiar with the committee's responsibilities as well as the rationale for the existence of the committee. 
Becoming familiar and experienced with collegial processes in professional associations contributes to success in the respective libraries. Working effectively in groups to examine issues critically and to attain a positive consensus in decisions is a collegial skill that is valued in librarianship (Frank 1997: 308). This collegiality has helped bring librarians together. As stated earlier, the need for belonging has played a significant role in retaining membership.

It is evident that library associations have a role to play and have been playing this role for decades. The professional librarian spends many years training to qualify as a librarian or information worker and relies on the professional association to provide professional support for issues such as intellectual freedom and support for professional development through the association's publications and conferences. It is the opinion of the author that the need for unity plays a significant role, as discussed above, in keeping the association together as a united and cohesive professional body which serves as the building block for all professional support mechanisms, be it for security, research publications or personal professional development. Therefore, it is imperative that a transformed organization continue to pay heed to the factors that have kept professional LIS organizations together. There would be a need to build on some of the issues mentioned above together with incorporating new issues that would make the organization more relevant to the South African LIS environment and also meet the needs of those employed within the sector.

This transformation must be viewed against the backdrop of the transformation of LIS representation in South Africa from an occupational association to a professional association and back to an occupational association. Before engaging in the discussion of the transformation, it is important to examine what the employees want from their representative organisation.

\section{Needs assessment}

Any organisation wanting to chart a new way forward would have to take into consideration what the employees would want from their representative organization. Research conducted by Kagan (2002) reveal that members of the LIS profession expressed the need for an organization to address their industrial concerns. These include, amongst others, salary increases and terms and conditions of employment and to engage in training and development. The study also found that members wanted the profession to be more inclusive of support staff.

The findings of research conducted by Raju (2005) are very similar to that of the Kagan (2002) study. Respondents expressed the view that the professional body needs to assume the role that their respective trade unions are currently playing in addressing their industrial concerns. They are of the opinion that their representative organisation must have knowledge of the sector and the discipline as opposed to experience and knowledge that the generic trade unions possess in negotiation (Raju 2005).

The one area in which LIS trade unions, at the international level, have played a proactive role is staff training and development. Authors such as Nyren (1967), Marsh (1980) and Akers (1985) argue that formal education and training influences the growth of unionism as it is linked to pay, grading, recruitment and the status within the occupation. Given the positive spin-offs of education and training, the representative body must ensure that the opportunities are available to all its members, especially for those who were not free to undertake full-time study to qualify as professional librarians.

The literature reveals that the LIS profession is fragmented. It is fragmented by the type of clientele it serves, by size, by source of financial support, and by a range of occupational groups working within the library. Kleingartner and Kennelly (1975), Kusack (1984) and Coleman (1988) point out that the above fragmentation is exacerbated by the fragmented representation of LIS employees as they belong to different bargaining units or they have their own independent library union or they may be lumped into larger, more generic unions. It is argued that this fragmentation severely retards the possibility of unifying the profession under a single viable representative body.

The fundamental purpose of having representation by a single organisation is to unify the profession to project a consolidated profession, with certain levels of diversity but with a single representative body. The literature reveals that a unified profession fosters closer working relationships between individuals within the profession (Stockham 1979). Unity in the profession also provides a single platform for the sharing of knowledge and experience through workshops and conferences. Staff training and development becomes much easier if it is implemented and supported by personnel who have the relevant knowledge and experience of the profession.

The findings of the research conducted by Kagan (2002) and Raju (2005) reveal that there is a need for the professional association to take charge in unifying the LIS sector. The view of the respondents in the Raju (2005) study was that the professional association has the depth of knowledge and experience of the sector, and the capacity to make the most effective representation possible. 


\section{Transformation of representation up to the current situation}

Representation by the professional association in South Africa has changed drastically since the 1930s. There has been a move away from racially divided organizations and organizations divided along ideology to one organisation representing the LIS profession as a whole. It is important to trace this transformation process to determine the extent of further change, if necessary, in determining a way forward. There are principles of old that need to be revisited and maybe readopted to make the new LIS organization more representative of the needs of the country and the people employed within the LIS sector.

\subsection{From SALA to SAILIS}

The South African Library Association (SALA) was formed in 1930. In those early days it was an occupational association of all persons who worked in libraries or who were interested in libraries or librarianship. Subsequently, the organisation began to forge ahead toward professionalism. To support its move towards a professional association, the Association periodically reviewed the possibility of acquiring statutory status. However, the move toward statutory status did not come to fruition.

The move towards a professional association was hampered by the fact that the Association accepted as its members all persons who worked in libraries, including 'non-professionals'. In its drive towards professionalisation the Association, over a period of time, began to review its membership policy. This review was to ensure that it came as close as possible to meeting the requirements of a professional association. The Association engaged in a process of continually revising the qualifications for membership which was of significant importance for the Association to change from an occupational association to a full professional association.

However, it is suggested by Dick (200I: 90) that the continual revision of qualifications was a façade for a push towards the segregation of the library profession along racial lines. The segregation of SALA came at the historic 1962 Annual Conference where the decision was taken to establish racially segregated library associations. Lor (1996: 242-243) argues that it was at this conference that SALA took a regressive step that has haunted the library profession in South Africa ever since. "The conference approved a motion that limited SALA's membership to whites and agreed to the establishment of separate library associations for 'Bantu', 'Coloureds' and 'Indians'”(Lor 1996: 242). A prominent group of SALA members formed a Consultative Committee for the Establishment of Library Associations for the Non-White Racial Groups, which helped establish these separate library associations for the three racial groups, that is, the Central Bantu Library Association, the Cape Library Association (for 'Coloureds'), and the South African Indian Library Association. According to Lor (1996: 243), "of the three associations only the Central Bantu Library Association survived [and was] later renamed the Bantu Library Association of South Africa, which became the African Library Association of South Africa (ALASA) in 1972".

The 197I SALA conference is viewed as another turning point in the move towards becoming a professional institute. The conference adopted a motion to prescribe the minimum requirements for professional membership. The prerequisite was an academic background and six years experience of information work. This motion was implemented in 1973 (Louw 1990: 148-I50).

The consolidation of the attempt to limit membership in the quest for professionalisation came in 1978 when it was confirmed that persons who did not comply with the professional requirements be classified as members without voting powers and may not serve as office-bearers but enjoy all other privileges of membership. Further, there was a motivation to change the name from an association to an institute to indicate a strong professional body with a scientific element. In 1980 SALA became the South African Institute for Librarianship and Information Science (SAILIS) (Hooper 1986: 19; Louw 1990: 151).

\subsection{African Library Association of South Africa (ALASA)}

Manaka (1981: 76) claims that

the birth of the Association resulted from the adoption of a motion by the South African Library Association in 1962 to restrict its membership to whites only and to form separate library associations for the other race groups.

The achievements of ALASA were not as notable as that of SALA or SAILIS. This limited success must be viewed against the backdrop of poor funding and the low levels of qualifications among the black people in the formative days of the Republic of South Africa. ALASA did hold conferences regularly. These conferences were used to promote the idea of a library, the use of books among blacks and the adoption of reading as an important component of education and development. Manaka (198I: 79) claims that one of the greatest contributions of ALASA was the Association's ability to bring together persons engaged in library work and for them to know and inspire one another.

SA JnI Libs \& Info Sci 2006, 72(2) 
When SAILIS opened its membership to include professionally qualified black librarians, many blacks who met the criteria joined the Institute. However, there were those who did not join and those who held dual membership (of SAILIS and ALASA) as they supported those blacks who did not qualify for membership of SAILIS. Further, it was held that there were problems that were specific to African librarians which could only be addressed through ALASA (Syphus 1995: 3-4).

\subsection{Library and Information Workers' Organisation (LIWO)}

There was a third formal library organisation that made its presence felt within the South African library and information environment. Syphus (1995: 2) is of the opinion that LIWO was formed in protest against the nonchalant attitude of SAILIS with regard to government policies and their effect on libraries and librarianship. The opinion of Syphus is confirmed by Merrett (200 I: 31) who stated that LIWO challenged the library establishment which had collaborated with the apartheid regime "... by failing to speak out and act against restrictions on the flow of information and curtailment of the freedom of expression".

In the opinion of Merrett (200I: 32-33), LIWO was committed to professional standards within a progressive context. It believed that the oppressed people of South Africa deserved a high quality, appropriate library and information service to drive the acquisition of knowledge essential to a healthy democracy (Merrett 200I: 33).

Of the three formal library organisations, SAILIS was generally held to be the one that had a more comprehensive infrastructure, greater membership and, on the whole, was the more 'successful' professional organisation in South Africa. However, it became more and more evident that the Institute was becoming irrelevant. In 1987, the Institute questioned its relevance especially in terms of its statutory recognition. It was envisaged that SAILIS should be providing leadership as well as acting as a forum for the discussion of issues such as professional status, conditions of service and compensation. Furthermore, it was envisaged that SAILIS would take the lead in the development of education and training and the establishment of a national information policy. However, it was becoming increasingly difficult to provide the necessary leadership and guidance as there was the growing question of the credibility of the Institute (Syphus 1995: 5).

The growing lack of credibility forced the Institute to do some introspection. The Institute's leadership began to look at what was best for the library and information community rather than what was best for the Institute. In fact, Matthee (1997: 25) pointed out that the "library and information profession has been plagued by the absence of a unified, strong and inclusive professional association for a number of years" as the LIS associations were divided along racial, political and specialised lines.

According to Kagan (200I: 15), the need for a 'one voice' policy was not unique to South Africa. Kagian states that SAILIS argued, with the support of the International Federation of Library Associations and Institutions (IFLA), that there should be only one association for a unified lobbying of the new ANC Government. ALASA eventually supported the argument by SAILIS and hence the merger between the two associations. However, LIWO refused to collaborate as it argued that the new organisation would be dominated by SAILIS people, ideas and resources as SAILIS was by far the largest and strongest organization.

\subsection{Library and Information Association of South Africa (LIASA)}

In July 1997, the two dominant (in terms of membership) professional associations were dissolved and LIASA was launched. The aims of LIASA are broad and encompassing. It is evident that there is an attempt to make the organisation all inclusive in terms of membership. There is a deliberate effort to contribute to the transformation process of the country through the provision of libraries and its services. An analysis of the aims of the organisation indicates that it is an organisation that would strive to unite the people that are working or interested in LIS. The constitution addresses a number of factors that have been identified as factors contributing to the retention and growth of the membership of a professional association. The constitution addresses, inter alia, the issue of unity, the need to belong, training and development, and good communication. A clear positive for the Association is the fact that these factors have the potential to affect a potentially wider membership community. The wider membership and the organisation will also address issues of standards, ethics and intellectual freedom, amongst others (LIASA 2000: 2).

The constitution of LIASA states that it "... is a voluntary association which represents persons engagecl or interested in library and information services (LIS) in South Africa." (LIASA 2000: 2). The issue of accepting all persons engaged or interested in librarianship was also central to the constitution in the formative years of SALA. As Louw (1990) pointed out, SALA made a concerted effort to evolve from an occupational association to a professional association. Such a transformation would take librarians and librarianship closer to meeting the attributes of a professional organisation. Further, the transformation would see the materialisation of a professional organisation, with professional librarians providing leadership to an organisation which, for all intents and purposes, was going to address professional issues. The current association representing library and information workers in South Africa seems to have gone a full circle in that it 
has transformed from an association representing the occupation to a professional association, and now back to an association representing an occupation.

If the argument that between the years 1948 to 1980 there had been a drive toward professionalisation of the professional association is accepted, then the author argues that LIASA is not a professional organisation per se but rather an occupational association. Such a paradigm shift places the association in a state of limbo in that it has consciously moved away from being an exclusively professional association back to being an occupational association. Therefore, the new association cannot enjoy the status of a professional association. At the same time it is not a statutory body and therefore cannot enjoy the privileges of a trade union.

In the author's opinion, there are advantages to opening the membership to all individuals employed in the LIS sector. It would ensure that a wider community seeks support from belonging to an organisation, a wider community feeling professionally secure under the banner of a professional body, a wider community benefiting from personal development and, a more informed LIS employee community.

There is clear intent on the part of LIASA to make the organisation as representative of the library and information environment as possible. Further, there is intent to make provision for growth and development of all employees within the library and information environment.

\section{Statutory professional representation}

Statutory status could be achieved through registration via the LRA 66 of 1995 or the promulgation of an Act specific to the discipline. In pursuing the investigation into the acquisition of statutory status, the author explored the following scenarios:

Scenario I: statutory status via a new legislation that is specific to the discipline;

Scenario 2: statutory status via existing legislation, namely, the LRA 66 of 1995 which will result in unionisation; and

Scenario 3: statutory status via an independent legislation and the LRA.

The case studies of the Health Professions Council of South Africa (HPCSA), the Association of Professional Educators of KwaZulu-Natal (APEK) and the South African Council of Educators (SACE) are used to inform the debate in seeking resolution to a way forward for the LIS sector.

\subsection{Scenario 1: Case study of HPCSA}

The HPCSA is a statutory body, established in terms of the Health Professions Act 56 of 1974. It is mandatory for all practising health profession to register with the Council which serves to safeguard the public and indirectly the professions, by ensuring that high standards of ethical and professional practice are consistently maintained.

The objectives of HPCSA are to:

- Promote the health of the population;

- Determine standards of professional education and training; and

- Set and maintain excellent standards of ethical and professional practice.

Currently South African practising health professionals, student health professionals, as well as foreign qualified health professionals who wish to practise in South Africa, are required to register with the HPCSA under the auspices of the relevant professional board. Foreign qualified health professionals, in most instances, are required to meet specific requirements and complete an examination prior to registration as health professionals in South Africa.

Subscriptions to the HPCSA are collected primarily through debit orders. If the member does not pay then she/he is removed from the register and therefore cannot practise in South Africa. Their prime function is to protect the public by regulating those that can apply their profession in South Africa. It accredits the institutions that produce the practitioners (De Silva 2005; Pillay 2005).

\subsection{Scenario 2: Case study of APEK}

APEK was established in October 1994 in terms of the Labour Relations Act 66 of 1995. It is mandatory for all educators to become members of any one of the trade unions that service the education sector. The objectives of APEX, amongst others, are to:

- promote, protect and maintain the rights of educators in general and those of its members in particular;

- negotiate on behalf of its members on matters affecting their rights, needs and interests;

- foster an interest in, and promote a respect for, education, by engaging its members in on-going study of and research into educational matters;

- promote or challenge any law or regulation, or proposed law or regulation, that affects the interest of education in general and/or its members in particular;

- promote the development of a single recognised General Teaching Council with authority to regulate and articulate 
those high professional standards needed to guarantee a teaching service of quality; and

- negotiate on behalf of its members on matters of concern to them, and to represent its members in collective bargaining structures, and to conclude agreement.

(APEK 1994)

APEK is an organisation with approximately 7000 members. Membership is open to any person possessing a teaching qualification recognised by the South African Council for Educators. All persons who are employed at an educational institution that is recognised by APEK, and who provide a service that is supportive of the education prograrnme offered by the institution, and are in regular contact with the learners may be eligible for full membership. These would include librarians, administrators, laboratory assistants and technicians (Pearce 2005).

All persons who qualify for full membership, but not currently holding a recognised post may be eligible for associate membership. Associate members shall be entitled to the privileges of full membership except that they shall not have voting rights nor shall they be eligible to hold office or serve on the Executive Council (Pearce 2005).

\subsubsection{Structure}

APEK has a president, a deputy president and six vice presidents. There are vice presidents for Finance, Education Matters, Professional Development, Membership, Communication and Conditions of Service. The Vice President for Professional Development and his/her team have the responsibility of dealing with the professional issues of the education profession (the professional association component) while the Vice President for Conditions of Service deals with the industrial component of the education profession, that is, trade union aspects. The union has a national negotiator and a full time shop steward (Pearce 2005).

\subsubsection{Activites of APEK}

APEK has its own newsletter and produces other publications that contribute to the educational process. They are part of the Public Service Co-ordinating Bargaining Council. Subscriptions are through stop order and in some cases debit orders. Teachers who are not affiliated to any union are required to pay a union subscription to the Council (one percent of their salary) which would then distribute these earnings among all four unions of the Council (Pearce 2005).

The Union (APEK) also belongs to the education SETA and is in the midst of developing an accreditation process. APEK is active in an exchange programme with Denmark via the Danish Cultural Institute. Educators from South Africa go to Denmark to get a sense of the education process together with doing some teaching. This is a two week programme. Danish educators come to South Africa for the same purpose. The entire cost of this exchange programme is covered by the Danish Cultural Institute (Pearce 2005).

\subsection{SACE}

SACE was established in 1995 through a collective agreement in the Education Labour Relations Council (ELRC). SACE is seen as an extension of the ELRC and NOT as a professional body which promotes and controls the profession (Republic of South Africa 2000: 1-2). The purpose of SACE is to:

- regulate the entrance of educators into the educational process through the registration of educators;

- discipline educators if they are in breach of the code of conduct; and

- pursue with professional development.

The purpose of ELRC is to maintain labour peace, that is, to provide a forum for the negotiation of disputes that are specific to the education sector. Collective agreements pertaining specifically to educators are concluded at the ELRC. The more general public service sector collective agreements are concluded at the Public Service C.o-ordinating Bargaining Council. All educators practising their 'trade' in South Africa must be registered with SACE. SACE will not accept anyone as a member without the minimum prescribed academic qualification. In the initial stage of the launch of SACE, there was a window period of three years for educators to acquire the minimum academic qualifications to function as educators in South Africa. At the end of that window period, only those with the minimum academic qualification could become members of SACE; only registered members of SACE could apply their 'trade' in South Africa. Employees in the education sector belong to SACE, the ELRC and their union. Subscription to SACE is R2.00 per month and R2.50 per month to the ELRC - both are compulsory (Pearce 2005).

\section{Scenario 3: Statutory status via the LRA 66 of 1995 and new sector specific legislation}

One of the major stumbling blocks of scenario I is that it perpetuates a fragmented LIS profession. If the LIS body registers as a statutory professional body, then the large cohort of support staff will be left by the wayside. A major stumbling block of scenario 2 is that there is insufficient focus on the development of the profession as al whole. The professionals in the sector are neglected. 
The registration as a trade union, similar to that of APEK, would ensure that all in the sector would have representation by an organisation that is familiar with the sector. The registration of the academically qualified personnel of the sector with a statutory body similar to HPCSA and SACE would address the professional component of the sector. In essence, it would be a subset of a larger statutory body, that is, the trade union. This trade union, specific to the sector, will be an affiliate to the various generic unions that address the industrial concerns of the various sectors. The author presents this as a third possible scenario for the LIS profession.

\section{Discussion, conclusion and recommendations}

It is evident that the need for belonging, library ethics, professional development, security, self help, intellectual freedom and such are factors that have contributed significantly to the continued existence of professional associations. Therefore, irrespective of the direction that the South African LIS sector takes as a way forward, these factors, which have stood the test of time, must form the core guiding principles of the 'new' organisation. It is also evident that there has been over the years, a conscious decision by the LIS representative body, to evolve from an occupational association to a professional association and back to an occupational association. Serious consideration must be given to this evolutionary process and any debate on the way forward should include the need either to start a new cycle towards professionalism or to maintain the current cycle of an occupational association with possible statutory status. The research conducted by Kagan (2002) and Raju (2005) on needs of those that work in the LIS sector indicates that workers in the profession would prefer to have the professional association address their industrial concerns and keep the profession united. The industrial concerns of the sector need to be prioritized to determine the role it would play in the debate for a way forward.

The author has presented three scenarios as possible ways forward for the LIS sector. The fundamental purpose of a statutory body, in terms of scenario one, is to protect the public, accredit the institutions that are producing practitioners and to regulate those that are practising the profession. Further, these organisations represent the interests of the academically qualified or student professionals. In terms of scenario two, the fundamental purpose of APEX, as a statutory body, is to protect educators and learners, and address both industrial and professional interests of educators.

A critical question is: Why is it necessary to acquire statutory status? If the response is that there is concern about the 'decline' of the profession and that there is a need to protect the provision of a LIS service to the different user communities, then scenario one would be appropriate. If the concern is about poor representation during bargaining processes and the lack of attention to the LIS sector with regard to their industrial concerns, then scenario two would be appropriate. However, if the concern is double-edged and that both issues are of concern then scenario three would be better able to address these concerns. An evaluation and prioritisation of the concerns of those that work in the sector will determine the most appropriate way forward to address the primary concerns and hopefully 'touch base' with the secondary concerns.

Given that the decision on a way forward affects the sector or the profession as a whole, it is recommended that the options be debated by all who are employed in the sector. A referendum on the issue of statutory status, in the opinion of the author, should be conducted to ensure buy-in by all in the sector. If there is minimum dissention from the sector, the path towards statutory status would be less problematic. In fact, consensus will reinforce an application for statutory status.

\section{Acknowledgement}

The author would like to acknowledge the National Research Foundation of South Africa for funding this investigation.

\section{References}

Akers, K. 1985. LAGSA: an experiment in employee participation and unionisation. Australian library journal, 34(2): 23-27.

APEK. 1994. Association of Professional Educators of KwaZulu-Natal. Visited on 15/07/2005 at http//www.apek.co.za.

Babbie, E. and Mouton, J. 2005. The practice of social research. Cape Town: Oxford University Press.

Coleman, M. 1988. Librarians and the Labour Relations Act. New Zealand libraries, 45(I2): 27I-272.

De Silva, H. 2005. Telephone communication with administrator of HPCSA. 25 August 2005.

Dick, A.L. 200I. Science or ideology? P.C. Coetzee and the professionalisation of South African librarianship. Perspectives in education, 19(3): 85-108.

Fisher, B. 1994. Professional organisations and professional development. British journal of academic librarianship, 9(3): 167- 178.

Frank, D.G. 1997. Activity in professional associations: the positive difference in a librarian's career. Library trends, 46(2): 307319.

Garry, L.S. 1977. Canadian library associations. In Garry, L.S. and C. Garry (eds.). Canadian libraries in their changing environment. Canada: York University. pp. 315-342.

Hooper, A.S.C. 1986. SAILIS: possible future directions. Wits journal of library and information science, 4: 19-32.

Kagan, A. 200I. Living in the real world: a decade of progressive librarianship in the USA and in international library organisations. Innovation: appropriate librarianship and information work in Southern Africa, 22: 11 - 19. 
Kagan, A. 2002. The transformation of South African librarianship: survey results and analysis of current opinions. Innovation: appropriate librarianship and information work in Southern Africa, 25: I-19.

Kleingartner, A. and Kennelly, J.R. 1975. Employee relations in libraries: the current scene. F.A. Schlipf (ed.). In Collective bargaining in libraries. Illinois: University of Illinois, Graduate School of Library Science. pp. I-22.

Kusack, J.M. 1984. Unions for academic library support staff: impact on workers and the workplace. New York: Greenwood Press. LIASA. 2000. LIASA Constitution. [Online].Available:http//home.imaginet.co.za/ liasa/constitution.html. Accesed I5 July 2005

LIASA. 2004. LIASA Annual General Meeting. LIASA Seventh Annual Conference, Polokwane, 27 September - I October.

Lor, P.J. 1996. A distant mirror: the story of libraries in South Africa. Daedalus, I25: 235-265.

Louw, A. 1990. Evolution from occupational association to professional institute. South African journal of librarianship and information science, 58(2): |47-|54.

Manaka, S.P. 198I. The African Library Association of South Africa: its role on the black library scene. South African journal for librarianship and information science, 49(2): 76-80.

Marsh, P.R. 1980. White collar unions in libraries. Sheffield: Sheffield University, Postgraduate School of Librarianship and Information Science.

Matthee, T. 1997. LIASA: unity and new beginnings. Cape librarian, September/October: 25-29.

Merrett, C. 200I. Voices of dissent: LIWO, civil rights and the library community in South Africa in the 1990s. Innovation: appropriate librarianship and information work in Southern Africa, 22: 30-34.

Nyren, 1967. Libraries and labor unions. Library journal, I June: 2II5-2I2I.

Oppenheim, C. and Pollecutt, N. 2000. Professional associations and ethical issues in LIS. Journal of librarianship and information science, 32(4): 187-203.

Pearce, A. 2005. Personal communication with CEO of APEK. 10 and 22 August 2005.

Pillay, D. 2005. Telephone communication with administrator of HPCSA. 24 August 2005.

Raju, R. 2005. Unionising library and information staff in the tertiary sector: a feasibility study. Unpublished PhD thesis. Pietermartizburg: University of KwaZulu-Natal.

Republic of South Africa. Statutes of the Republic of South Africa. 2000. South African Council of Educators Bill. Pretoria: Government Printer.

Rossman, G.B. and Rallis, S.F. 1998. Learning in the field: an introduction to qualitative research. London: Sage.

Stabbins, P.A. 1990. A comparative analysis of internationally selected library code of ethics: with particular reference to the code proposed by the South African Institute for Librarianship and Information Science. Unpublished MIS thesis. Pietermartizburg: University of Natal.

Stockham, K. 1979. The role of the professional association in librarianship. An Leabharlann, 8(2): 22-25.

Sullivan, P. 1976. Library associations. Library trends, 25(I): I35-I52.

Syphus, M. 1995. Toward a LIS association for all: a critical assessment of the position of SAILIS with regard to a unified profession. South African journal for librarianship and information science, 63(I): I-8.

Virgo, J.A. 1991. The role of professional associations. In C.R. McClure and P. Hernon (eds.). Library and information science research: perspectives and strategies for improvement. New Jersey: Ablex. pp. 189-196. 